\title{
School-family-community partnerships: supporting underserved students in the U.S.
}

\author{
Susan J. Paik, Shirlie Mae Mamaril Choe, Charlina Gozali, Christine W. Kang \& Anais Janyan \\ Claremont Graduate University - California (U.S.)
}

\begin{abstract}
The importance of school-family-community (SFC) partnerships have long been established; however, more research, practices, and policies are needed to better understand and support diverse socio-cultural contexts of children from underserved communities in the U.S. Using Epstein's model on SFC partnerships as the conceptual framework, the purpose of the article is to discuss key influences, barriers, and opportunities in developing best practices for successful collaborations in culturally and linguistically diverse communities. The article discusses and provides practical examples of how barriers such as cultural disparities between the home and school, parents' and teachers' roles in education, language difficulties, another constraint faced by families can be addressed to foster SFC partnerships. Education stakeholders - teachers, school leaders, parents, and community members - need to establish appreciation, trust, and respect towards each other and learn to value the unique knowledge that each brings to the education table. When education stakeholders are engaged in strong partnerships, students' academic and nonacademic outcomes are enhanced.
\end{abstract}

Keywords: School-family-community partnerships, diversity, underserved communities.

\section{Relación Centro Escolar-Familias-Entidades Comunitarias: Apoyo a los estudiantes en riesgo de exclusión social en Estados Unidos}

\section{RESUMEN}

La importancia de la colaboración escuela-familia-comunidad (SFC) ha sido establecida desde hace mucho tiempo; sin embargo, se necesita más investigación, prácticas y políticas para comprender y apoyar mejor los diversos contextos socioculturales de niños de comunidades marginadas en los Estados Unidos. Utilizando el Modelo de Epstein sobre la colaboración SFC como marco conceptual, el propósito de este artículo es discutir influencias clave, barreras y oportunidades en el desarrollo de mejores prácticas para colaboraciones exitosas en comunidades cultural y lingüísticamente diversas. El artículo analiza y proporciona ejemplos prácticos de cómo las barreras como las disparidades culturales entre el hogar y la escuela, los roles de los padres y los maestros en la educación, las dificultades del idioma y otras restricciones que enfrentan las familias pueden abordarse para fomentar la colaboración SFC. Las partes interesadas en la educación (maestros, líderes escolares, padres y miembros de la comunidad) necesitan establecer aprecio, confianza y respeto entre sí y aprender a valorar el conocimiento único que cada uno aporta a la educación. Cuando las partes interesadas de la educación participan en colaboraciones sólidas, se mejoran los resultados académicos y no académicos de los estudiantes.

Palabras Clave: Colaboración escuela-familia-comunidad, diversidad, comunidades vulnerables.

\section{Introduction and Significance of the Topic}

For decades, researchers have long been interested in schoolfamily-community (SFC) partnerships. While they may not have been initially termed as "partnerships," it was evident that practices to include families in educational processes were considered essential (Chavkin, 2001). However, such practices have not always considered children's experiences within sociocultural contexts of diverse families and communities (DotsonBlake, Foster \& Gressard, 2009; Lavadenz \& Armas, 2011; Redding, Murphy \& Sheley, 2011; Thao, 2003). Over the years, demographic factors such as race and class have been identified as important influences in children's educational experiences (Bryan, 2005; Díez, Gatt \& Racionero, 2011; Grant \& Ray, 2010; Smit \& Driessen, 2005). Since then, many researchers and policymakers in the U.S. and elsewhere have acknowledged the need to understand children's backgrounds in order to develop effective partnerships in diverse communities (Díez et al., 2011; Fantuzzo, McWayne, Perry \& Childs, 2004; Hill \& Torres, 2010; Ho, Fox \& Gonzalez, 2007; Paik, 2011; Paik \& Walberg, 2007; Patrikakou, Weissberg, Redding \& Walberg, 2005).

Effective partnerships have been found to be instrumental in helping children to develop social, emotional, and academic skills, especially those from underserved communities (Albright, 
Weissberg \& Dusenbury, 2011; Aponte, 1976; Bailey \& BradburyBailey, 2010; Bryan, 2005; Ferguson, 2008; Patrikakou et al., 2003; Redding et al., 2011). Epstein (2005) reported studies which showed the impact of family and community involvement on student outcomes (e.g., achievement, attendance, course taking, class preparation). Families, schools, and communities can support children's learning and development; however, they have not always been mobilized as resources in this endeavor (Epstein, 2005; Epstein et al., 2009; Patrikakou et al., 2003). Collaborative efforts can support positive development through increased communication and recognition of the child's social and cultural context of learning (Paik, 2011; Paik \& Walberg, 2007; Patrikakou et al., 2003; Rodrigo, Martínez-González \& Rodríguez-Ruiz, 2018).

The purpose of this article is to discuss key influences, barriers, and opportunities in developing best practices for successful SFC collaborations, particularly in culturally and linguistically diverse communities in the U.S. To better understand and support underserved communities, the article will do the following: 1) present past policy perspectives, 2) use Epstein's SFC model (Epstein et al., 2009) to guide the discussion on barriers and opportunities in developing partnerships in diverse communities, 3 ) provide brief demographics on diverse U.S. populations, 4) highlight some research findings and best practices by providing SFC examples, 5) discuss the role of parents, teachers, and communities, and 6) conclude with recommendations for research, practice, and policy to serve diverse communities.

\section{Past policy perspectives: building partnerships in underserved communities}

In the early 2000s, several publications were written in response to educational policies and programs funded by the U.S. Department of Education (Albright et al., 2011; Bailey \& BradburyBailey, 2010; Brown, Muirhead, Redding \& Witherspoon, 2011; Moles, 2003). Policies such as No Child Left Behind (2001) (U.S. Department of Education, n.d.) and Title I (1965) (U.S. Department of Education, 2007) had specific provisions for parent involvement to address any barriers to participation from traditionally underserved communities. Alongside academics, increased emphasis was also placed on social and emotional skills for students. Policies and programs also included support for strengthening home learning, coordinating parent partnerships, and involving communities (U.S. Department of Education, 2007; U.S. Department of Education, n.d.)

Title I emphasized the importance for partnerships, particularly for schools and families. While the early research findings on parent involvement from partnerships varied, parents did report more home-based involvement when schools provided more comprehensive program support (e.g., home learning materials and resources) (Moles, 2003). From these findings, the policy of Title I (U.S. Department of Education, 2007) schools may have an indirect influence on achievement as stronger home-based learning was linked to reading achievement in these schools (Moles, 2003). However, some researchers have found limitations in the family engagement literature and implementation of partnership programs in low-achieving schools (Brown et al., 2011; Chavkin, 2001). For instance, if some studies reported high parental involvement, it was not clear whether school initiatives or actions influenced parental involvement (Brown et al., 2011; Moles, 2003). Nevertheless, communication was found to be one of the key factors to parental involvement in these studies (Brown et al., 2011).
Research shows that consistent communication between schools and parents are key to monitoring children's educational progress, especially for underserved communities (Díez et al., 2011; Grant \& Ray, 2010; Patrikakou et al., 2003). The No Child Left Behind Act of 2001 (U.S. Department of Education, n.d.) recognized the importance of strong communication when it defined parental involvement as consisting of "regular, two-way, and meaningful community" (Patrikakou et al., 2003, p. 1). To ensure positive outcomes, researchers advised federal grantees to continue with "deliberative, focused, and comprehensive" family engagement programs even after the end of the funding period (Brown et al., 2011, p. 2). Moreover, current and future programs need to be continually monitored and evaluated for effectiveness (Moles, 2003). Fortunately, new initiatives in the U.S. have continued to focus on cultivating these partnerships.

\section{Conceptual framework: epstein's model on SFC partnerships}

As one of the most cited and used SFC theories, Epstein's model emphasizes the shared interest and responsibility of children's education from families, schools, and communities (Epstein, 2005; Epstein et al., 2009; Seattle Public Schools, 2017; Simon \& Epstein, 2001). These three "overlapping spheres of influence" partner together to support students at the center (Epstein et al., 2009). Each sphere models itself to emulate the other to better support the child: having more "family-like" schools "recognizes each child's individuality"; "school-like" families reinforces the importance of schoolwork and educational activities in the home; "communities-minded" families and schools help bridge each other's needs, while communities provide supplemental support for "school-like" opportunities to both families and schools (Epstein et al., 2009, p. 11). Adopted nationally in policy and school practices (e.g., Seattle Public Schools), Epstein's model emphasizes the importance of research-based SFC partnerships (Epstein, 2005; Seattle Public Schools, 2017; Simon \& Epstein, 2001).

This article will use the central ideas in Epstein's model to help illustrate the importance of developing SFC partnerships, in particular, for culturally and linguistically diverse families. While the model itself does not directly address diverse families and communities, the following six components are essential for relationship-building: communication, family support, student learning, welcoming environment, school/district decisionmaking and advocacy, and community collaboration partnerships (Epstein et al., 2009; Lavandenz \& Armas, 2011; MartínezGonzález, Martínez \& Pérez, 2004; Rodríguez-Brown, 2009). These key components and related practices are presented through research findings and best practices to understand and support racially, ethnically, and linguistically diverse populations.

\section{U.S. demographics: culturally and linguistically diverse populations}

Diverse populations are rapidly growing in the U.S. and their numbers are projected to increase in the near future (Ortman \& Shin, 2011; Rong \& Preissle, 2009). In 2005, there were about 11 million immigrant children in the U.S., representing one-fifth of the total school-aged population (Rong \& Preissle, 2009). The number of immigrant children is expected to continue to increase over time. In 2011, racial and ethnic children (younger than age 1) made-up more than half of all children born in the U.S. (U.S. Census Bureau, 2012). Similarly, the minority population also constituted approximately $50 \%$ of the population younger than age five (U.S. Census Bureau, 2012). 
The growing and diverse populations also come with linguistic diversity. Since many immigrant students come from Latin America and Asia, Spanish and several Asian languages are commonly spoken at home (Ortman \& Shin, 2011). English language learners (ELLs) are considered the fastest growing population in public schools, with nearly 80 percent speaking Spanish (Nieto \& Bode, 2012; U.S. Census Bureau, n.d.).

The diversity of children's backgrounds has profound implications for educators and other stakeholders. Limited English proficiency, cultural and racial barriers, and economic struggles present serious challenges for many students in the $21^{\text {st }}$ century. Without supportive interventions, many students from underserved communities will continue to struggle in school.

\section{Research and practice: serving underserved populations through sfc programs}

Effective SFC partnerships can support students who may be experiencing stressors or other barriers to school success (Bryan, 2005; Epstein, 2005; Epstein et al., 2009). In order for SFC partnerships to be effective, Epstein's model emphasizes communication, family support, student learning, a welcoming environment, school/district decision-making and advocacy, and community collaboration partnerships. To reduce barriers in developing partnerships, these key components are illustrated through research findings and best practices of SFC program examples in the U.S., in particular, for diverse communities.

\section{Importance of socio-cultural contexts: early approaches to SFC}

Over the years, researchers and practitioners have found benefits to collaborative efforts in educational communities. One of the earliest examples of partnerships was Aponte's (1976) case study on the use of the family-school interview, "an intervention with a child, family and school" (p. 303). To help children with any behavioral or academic problems, he stressed the importance of examining the child's position in several ecological contexts including individual, familial, school, and other socio-culturalpolitical contexts (e.g., generation, gender, and ethnic identities). Aponte (1976) describes the importance of the family-school interview since it emphasizes a collective effort with the key individuals in the child's world. Aponte purposefully identified the importance of ecological contexts as the key framework for this practice, bringing representatives together from the family, school, and community to support the child's social, emotional, and academic development.

\section{Supporting urban and low-income communities: beyond education}

SFC partnerships reinforce a positive environment for students and can help bridge achievement gaps based on structural factors (e.g., race, class, geography) (Bailey \& Bradbury-Bailey, 2010; Jeynes, 2007; Lavadenz \& Armas, 2011). However, it is not enough for teachers and educational leaders to acknowledge students' backgrounds; there has to be a concerted effort to address the barriers to family engagement (Lavadenz \& Armas, 2011; Quinton, 2013). Educational communities need parents, school staff, and out-of-school programs to fully address achievement gaps (Bailey \& Bradbury-Bailey, 2010). Since many families from underserved communities may have experienced negative interactions with schools in the past, consistent communication and support are key in cultivating relationships. Schools may need to exercise greater flexibility in order to accommodate parents' work schedules and obligations (Sheldon, 2003). Collaborations between schools and parents should also be respectful and responsive; school staff should be trained in increasing parental involvement; curriculum should be culturally relevant and academically rigorous; and accountability must exist for all stakeholders (Lavadenz \& Armas, 2011).

For a more community-centered approach, some schools also serve as Community Learning Centers (CLCs). CLCs are full-service schools or "community hubs...[for]recreational, educational, social, health, civic, and cultural opportunities for students, their families, and the community" (Evans \& Kamine, 2011, p. 122). CLCs provide holistic support for families by allowing educators to focus on teaching and having community partners address social, emotional, and mental health needs (Evans \& Kamine, 2011). For CLCs to be successful, barriers need to be addressed such as lack of trust, resistance to change, deficit perspectives towards families, or bureaucratic limitations to use outside professionals.

One such comprehensive model of a SFC partnership is the Roses in Concrete Community School in Oakland, California. Established by Jeff Duncan-Andrade, the school functions as "a center of health within the neighborhoods surrounding it" (Roses in Concrete Community School, 2016). Duncan-Andrade emphasizes the importance of meeting the needs of the whole community (Tagawa, 2014). The Roses in Concrete Community School prioritizes the needs of youth and their families by providing education, health, housing, and career services. Duncan-Andrade calls on schools, community organizations, and families to work together for effective outcomes (Wilson, $\underline{2015)}$.

\section{English language learners and immigrants: bridging culture and language}

Many studies on EL Land immigrant populations have been conducted on predominantly Spanish-speaking or Latino communities. Factors such as acculturation, language proficiency, socioeconomic status, and cultural values influence families' perceptions, practices, and participation in school (Durand, 2010; Hill \& Torres, 2010). Conchas (2001), for instance, found that even high-achieving Latino students reported feeling marginalized at school because of conflicts between the competitive culture of advanced courses and the cooperative environment of their homes. SFC partnerships need to be approached with sensitivity, understanding how culture and language play a role for students and their families.

An inclusive model of SFC partnerships respects the values, cultures, and languages of underserved families (Díez et al. 2011). Fostering inclusive schools begins in the classroom ( al., 2007). For example, teachers can incorporate bilingual signs in classrooms and schools and when possible, communicate to parents in their native tongue. Rodríguez-Brown (2009) emphasizes the need for schools to recognize the importance of culture and language for diverse communities. She found that strategies such as translation services, culturally relevant curriculum, and giving parents an opportunity to speak were instrumental in developing partnerships.

Dotson-Blake, Foster \& Gressard's (2009) study on Mexican immigrant families is an example of working with diverse families. Below is a summary of their recommendations:

1) A culture of respect and equal engagement: The entire school involves teachers, school leaders, and other personnel for 
building a community by bridging language and involving parents in the decision-making process.

2) Welcoming and collaborative environment: The physical environment can help parents feel a part of the school community. For example, translated information (e.g., bilingual signs or information) shows respect for diverse cultures and families.

3) Active community leaders and liaisons: Schools can identify individuals to serve as liaisons or cultural brokers between the school and community. Teachers, school leaders and other personnel can learn about community events.

4) Intentional and structured interactions: School counselors or other personnel can provide professional development to teachers and parents. All partners can collaborate and plan together.

5) Invest in reciprocal community engagement relationships: Partnerships must be reciprocal; all partners can share resources and services.

6) Reflection: All partners should reflect and evaluate efforts for sustainability.

\section{Research and practice: role of parents, teachers, school leaders, and communities parents}

As the child's first teachers, parents often establish the foundation for children's educational success. It is not surprising that most partnerships occur in the child's preschool years (Davis-Kean \& Eccles, 2003). Both parents and early childhood educators serve not only as academic teachers, but role models for social and emotional development. This initial guidance is necessary as children spend most of their time in the home and school; these two environments need to work together (Walberg \& Paik, 1997). Where home resources are lacking, the school can offer support. For example, many schools provide free lunches, social support, or access to community assistance. Parents can also provide support to schools (e.g., share educational and other resources, provide their expertise) (Davis-Kean \& Eccles, 2003).

Research on school-family partnerships appears to be more focused on elementary schools (Brown et al., 2011). One possible reason for the lack of research on partnerships in middle or high schools may be parents' reluctance in being involved with their adolescents' education. Beyer, Patrikakou \& Weissberg (2003) found that parents of adolescents tend to perceive high school teachers as wanting less of their involvement. At the same time, teachers may also believe that parents do not want to be involved. Nonetheless, the authors highlight that adolescents actually want their parents to be involved. In fact, adolescence may be the ideal time to establish strong partnerships for students due to various pressures. Schools, families, and teens should collaborate in efforts to address adolescent issues such as peer pressure, drug use, or college goals. In summary, parental involvement and collaboration needs to be continuous and systematic throughout different stages (Patrikakou et al., 2005)

The Parent Institution for Quality Education (PIQE) is an example of a parent-teacher partnership ("PIQE - Parents for Quality Education," n.d.). Originally started in Southern California, PIQE is an eight-week program aimed at equipping and coaching parents to support children's development through literacy awareness. PIQE provides helpful resources, support, and opportunities for building partnerships and educational awareness for parents in culturally and linguistically diverse communities. Some of PIQE's strategies for parents include support networks in and out of the program, parental involvement with homework, extracurricular activities, and college preparation (Golan \& Petersen, 2002).

\section{Teachers and school leaders}

Although parents may want to be involved, they may not always know how to provide the best support to their children. Teachers can increase parental involvement by regularly communicating with them about their children's academic progress and assessment (Martínez-González et al., 2004). Communicating goals and expectations, reporting information regularly, and establishing shared practices at school and home can also reinforce collaboration between parents and teachers (Martínez-González et al., 2004; Shockley, Michalove \& Allen, 1995).To engage more parents, schools also need to believe that parents offer valuable knowledge as partners in their children's education (Shockley et al., 1995). Roses in Concrete (described earlier) provided active support their parents and community. For instance, they implemented various forms of communication to provide classroom and school-wide notifications to parents; community networking was also available and encouraged (Roses in Concrete Community School, 2016).

Strong relationships between schools and home also depend upon educational leadership and staff (Epstein, 2005; Epstein et al., 2009; Grant \& Ray, 2010). Specifically, school counselors, psychologists, and social workers can help provide a welcome environment and advocate for families in need (Bailey \& Bradbury-Bailey, 2010; Bryan, 2005; Dotson-Blake et al., 2009; Grant \& Ray, 2010). They can also help to identify barriers to family involvement and partnerships, help families navigate unfamiliar policies, and facilitate an inclusive school culture (Bailey \& Bradbury-Bailey, 2010; Fantuzzo et al., 2004). School leaders can actively foster family engagement in schools by hiring dedicated staff to coordinate school-home collaborations, prioritizing professional development on family involvement, providing school-wide opportunities and engagement, and evaluating their diversity practices (Beyer et al., 2003; Grant \& Ray, 2010; Kirschenbaum, 2001; Redding et al., 2011). Roses in Concrete serves as an example where teachers and leaders are trained to teach and work with parents and communities in Oakland public schools (Tagawa, 2014).

\section{Communities}

Most studies on SFC partnerships tend to emphasize the role of parents in schools. However, in examining the experiences of immigrant and linguistically-isolated families, community empowerment can be the driving force behind building strong SFC partnerships (Delgado-Gaitan, 2001, 2004). DelgadoGaitan's (2001) ethnography of Mexican immigrant families in Carpinteria, California highlighted how a community can help address academic challenges such as high dropout rates. The families in the study spoke little to no English, often worked in plant nurseries, factories, or domestic service, and initially had very little school engagement.

After a series of community meetings to discuss their children's plight, COPLA (Comité de Padres Latinos/Committee of Latino Parents) was formed to provide an active voice for predominantly Spanish-speaking parents (Delgado-Gaitan, 2004). Meetings were held in Spanish to accommodate the parents; bilingual speakers were also available to translate for the English speakers, many of whom were school or district representatives. COPLA brought critical school information to parents, helped connect community members, provided leadership opportunities, and empowered families in their children's education. Members of COPLA tackled issues including the exclusion of Spanish-speaking students from gifted 
programs, limited English language support in classrooms, and low literacy rates.

Delgado-Gaitan's (2004) community-based research provides an example of how families and communities can take action. Her findings highlight the importance of two-way communication among key stakeholders (Delgado-Gaitan, 2004). Organizations like COPLA can help to facilitate ongoing communications and develop a supportive learning community (Delgado-Gaitan, $2001,2004)$. Schools need to share information with parents, but these institutions also need to learn what is happening with the child at home (Delgado-Gaitan, 2001, 2004). Parents, schools, and communities all share responsibility for children's needs and education (Epstein, 2005; Epstein et al., 2009). Communities can help facilitate more opportunities and support for children, families, and schools. In the case of culturally and linguistically diverse communities, it is even more important that schools reach out to families in their home language to be more inclusive.

\section{Conclusion and implications}

The Nigerian proverb - 'it takes a whole village to raise a child' - truly applies to the idea of successful school-familycommunity partnerships. Building upon Epstein's model that children are at the center of these overlapping spheres of influence, parents, teachers, educational leaders, and the wider community all have a vested interest in learning and success (Simon \& Epstein, 2001).

While past and current policy initiatives have emphasized the importance of collaborative efforts, there is still a need to build stronger partnerships with culturally and linguistically diverse families from underserved communities (DelgadoGaitan, 2004). In order to form effective partnerships, key barriers need to be addressed. These barriers include insufficient access to information, language barriers, inadequate resources, lack of cultural awareness, and limited leadership (Davis-Kean \& Eccles, 2003; Golan \& Petersen, 2002; Grant \& Ray, 2010; HiattMichael, 2008; Martínez-González et al., 2004; Shockley et al., 1995).

Successful collaborations require a positive school environment with conflict management, a shared responsibility in public relations, and a caring approach to all matters (HiattMichael, 2008). Schools should consider context and focus on the local needs of children and families in their communities (Hiatt-Michael, 2008; Patrikakou et al., 2003). To this end, schools need to promote an inclusive environment that respects cultural differences, supports community needs, and promotes shared leadership and decision-making (Hiatt-Michael, 2008).

The need for more research and evidence-based practices is also important in developing effective SFC partnerships (Chavkin, 2001). Future research should also include interdisciplinary approaches to fostering partnerships that support linguistic and cultural diversity (Grant \& Ray, 2010; Patrikakou et al., 2003). In addition, most SFC partnerships have focused on Latino and African American populations; more research on Asian Americans, Native Americans, families of students with disabilities, or other populations is needed (Paik et al., 2014; Paik et al., 2017a, 2017b; Redding et al., 2011; Thao, 2003). Hill \& Torres (2010) also recommend that future research consider cultural influences on achievement and gauge whether findings are generalizable across racial and ethnic backgrounds.

In summary, SFC partnerships are essential for students' academic and nonacademic outcomes, especially those from underserved communities. More specifically, understanding their unique contexts is essential for building successful partnerships. Finally, the involvement of key stakeholders from all levels is a requirement for successful school-familycommunity collaboration.

\section{References}

Albright, M. I., Weissberg, R. P., \& Dusenbury, L. A. (2011). School-family partnership strategies to enhance children's social, emotional, and academic growth. Newton, MA: National Center for Mental Health Promotion and Youth Violence Prevention, Education Development Center.

Aponte, H. J. (1976). The Family-School Interview: An EcoStructural Approach. Family Process, 15(3), 303-311.

Bailey, D., \& Bradbury-Bailey, M. (2010). Empowered Youth Programs: Partnerships for Enhancing Postsecondary Outcomes of African American Adolescents. Professional School Counseling, 14(1), 64-74. doi: https://doi.org/10.5330/ prsc.14.1.0vk554458027081n

Beyer, R. D., Patrikakou, E. N., \& Weissberg, R. P. (2003). Schoolfamily partnerships for adolescents. The LSS Review, 2(1), 1213.

Brown, J., Muirhead, M., Redding, S., \& Witherspoon, B. (2011). Changing the conversation with families in persistently low-achieving high schools: Guidance for implementation of school improvement grants. Lincoln, IL: Center on Innovation and Improvement. Retrieved from http://www. centerii.org/survey/downloads/Promising_Practices_ ChngTheConversation.pdf

Bryan, J. (2005). Fostering educational resilience and achievement in urban schools through school-family-community partnerships. Professional School Counseling, 8(3), 219-227.

Chavkin, N. F. (2001). Recommendations for research on the effectiveness of school, family, and community partnerships. In S. Redding, \& L.G. Thomas (Eds.), The Community of the School (pp. 83-96). Lincoln, IL: Academic Development Institute. Retrieved from http://www.adi.org/journal/ss01/ chapters/Chapter8-Chavkin.pdf

Conchas, G. (2001). Structuring failure and success: Understanding the variability in Latino school engagement. Harvard Educational Review, 71(3), 475-505.

Davis-Kean, P. E., \& Eccles, J. S. (2003). Influences and barriers to better parent-school collaborations. The LSS Review, 2(1), 4-5.

Delgado-Gaitan, C. (2001). The power of community: Mobilizing for family and schooling. Lanham, MD: Rowman \& Littlefield.

Delgado-Gaitan, C. (2004). Involving Latino families in schools: Raising student achievement through home-school partnerships. Thousand Oaks, CA: Corwin Press.

Díez, J., Gatt, S., \& Racionero, S. (2011). Placing Immigrant and Minority Family and Community Members at the School's Centre: the role of community participation. European Journal of Education, 46(2), 184-196. doi: https://doi.org/10.1111/ j.1465-3435.2011.01474.x

Dotson-Blake, K. P., Foster, V. A., \& Gressard, C. F. (2009). Ending the Silence of the Mexican Immigrant Voice in Public Education: Creating Culturally Inclusive Family-SchoolCommunity Partnerships. Professional School Counseling, 12(3), 230-239. doi: https://doi.org/10.5330/PSC.n.2010-12.230

Durand, T. M. (2010). Latina Mothers' Cultural Beliefs About Their Children, Parental Roles, and Education: Implications for Effective and Empowering Home-School Partnerships. The Urban Review, 43(2), 255-278. doi: https://doi.org/10.1007/ s11256-010-0167-5

Epstein, J. (2005). Developing and sustaining comprehensive programs of school, family, and community partnerships: 
Summary of five years of NNPS research. In Plenary Round Table. Oviedo, Spain. Retrieved from http://www.ernape.net/ conferences_oviedo2005_12.html

Epstein, J., Sanders, M. G., Sheldon, S., Simon, B. S., Salinas, K. C., Jansorn, N. R., \& Williams, K. J. (2009). School, Family, and Community Partnerships: Your Handbook for Action (3 edition). Thousand Oaks, Calif: Corwin.

Evans, M. P., \& Kamine, D. (2011). It takes a village. In H. Kreider \& H. Westmoreland (Eds.), Promising Practices for Family Engagement in Out-of-school Time (pp. 121-134). Charlotte, NC: Information Age Publishing.

Fantuzzo, J., McWayne, C., Perry, M. A., \& Childs, S. (2004). Multiple dimensions of family involvement and their relations to behavioral and learning competencies for urban, low-income children. School Psychology Review, 33(4), 467-480.

Ferguson, C. (2008). The School-Family Connection: Looking at the Larger Picture. A Review of Current Literature. National Center for Family and Community Connections with Schools. Retrieved from http://eric.ed.gov/?id=ED536948

Golan, S., \& Petersen, D. (2002). Promoting involvement of recent immigrant families in their children's education. Retrieved December 30, 2016, from http://www.hfrp.org/familyinvolvement/publications-resources/promoting-involvementof-recent-immigrant-families-in-their-children-s-education

Grant, K. B., \& Ray, J. A. (2010). Home, school, and community collaboration: Culturally responsive family involvement. Thousand Oaks, CA: Sage.

Hiatt-Michael, D. B. (2008). Teaching, curriculum, and community involvement. Charlotte, NC: Information Age Publishing Inc.

Hill, N. E., \& Torres, K. (2010). Negotiating the American Dream: The Paradox of Aspirations and Achievement among Latino Students and Engagement between their Families and Schools. Journal of Social Issues, 66(1), 95-12. doi: https://doi. org/10.1111/j.1540-4560.2009.01635.x

Ho, H.-Z., Fox, K. R., \& González, M. (2007). Making your classroom parent-friendly to families of English language learners. In D. B. Hiatt-Michael (Ed.), Promising practices for teachers to engage families of English language learners (pp. 6185). Charlotte, NC: Information Age Publishing Inc.

Jeynes, W. H. (2007). The relationship between parental involvement and urban secondary school student academic achievement: A meta-analysis. Urban Education, 42(1), 82-110. doi: https://doi.org/10.1177/0042085906293818

Kirschenbaum, H. (2001). Educating professionals for school, family, and community partnerships. In D.B. Hiatt-Michael (Ed.), Promising practices for family involvement in schools (pp. 185-208). Greenwich, CT: Information Age Publishing.

Lavadenz, M., \& Armas, E. G. (2011). Listening to parent voices: Home-school collaboration for diverse communities. In C. M. Hands \& L. Hubbard (Eds.), Including Families and Communities in Urban Education (pp. 99-118). Charlotte, NC: Information Age Publishing Inc.

Martínez-González, R. A., Martínez, R., \& Pérez, M. H. (2004). Children's school assessment: Implications for family-school partnerships. International Journal of Educational Research, 41(1), 24-39. doi: https://doi.org/10.1016/j.ijer.2005.04.004

Moles, Jr., O. (2003). School-family relations and learning: Federal education initiatives. The LSS Review, 2(1), 20-21.

Nieto, S., \& Bode, P. (2012). Affirming diversity: the sociopolitical context of multicultural education (Sixth edition.). Boston, MA: Pearson Education.

Ortman, J. M., \& Shin, H. B. (2011). Language Projections: 2010 to 2020. Presented at the Annual Meetings of the American Sociological Association, Las Vegas, NV.
Paik, S. J. (2011). Minority families and schooling. In S. Redding, M. Murphy, \& P. Sheley (Eds.), Handbook on Family and Community Engagement (pp. 121-124). Charlotte, NC: IAP.

Paik, S. J., \& Walberg, H. J. (Eds.). (2007). Narrowing the Achievement Gap: Strategies for Educating Latino, Black, and Asian Students. New York, NY: Springer Science \& Business Media.

Paik, S. J., Kula, S. M., Saito, L. E., Rahman, Z., \& Witenstein, M. A. (2014). Historical perspectives on diverse Asian American communities: Immigration, incorporation, and education. Teachers College Record, 116(8), 1-45.

Paik, S. J., Rahman, Z., Kula, S. M., Saito, L. E., \& Witenstein, M. A. (2017a). Diverse Asian American Families and Communities: Culture, Structure, and Education (Part 1: Why They Differ). School Community Journal, 27(2), 35-66.

Paik, S. J., Rahman, Z., Kula, S. M., Saito, L. E., \& Witenstein, M. A. (2017b). Ethnic Afterschool Programs and Language Schools in Diverse Asian American Communities: Varying Resources, Opportunities, and Educational Experiences (Part 2: How They Differ). School Community Journal, 27(2), 67-96.

Patrikakou, E. N., Weissberg, R. P., Manning, J. B., Redding, S., \& Walberg, H. J. (2003). School-Family Partnerships: Promoting the Social, Emotional, and Academic Growth of Children. The LSS Review, 2(1), 1-3.

Patrikakou, E. N., Weissberg, R. P., Redding, S., \& Walberg, H. J. (2005). School-family partnerships: Dimensions and recommendations. In E. N. Patrikakou, R. P. Weissberg, S. Redding, \& H. J. Walberg (Eds.), School-family partnerships for children's success (pp. 181-188). New York: Teachers College Press.

PIQE - Parents for Quality Education. (n.d.). Retrieved May 21, 2018, from https://www.piqe.org/

Quinton, S. (2013, November 11). Good Teachers Embrace Their Students' Cultural Backgrounds. The Atlantic. Retrieved from http:/www.theatlantic.com/education/ archive/2013/11/good-teachers-embrace-their-studentscultural-backgrounds/281337/

Redding, S., Murphy, M., \& Sheley, P. (2011). Handbook on Family and Community Engagement. Lincoln, IL: Information Age Publishing, Inc. and Academic Development Institute.

Rodrigo López, M. J., Martínez-González, R. A., \& RodríguezRuiz, B. (2018). La relación centro escolar-familia como factor protector de conductas transgresoras en la adolescencia. Aula Abierta, 47(2), 149-158. doi: https://doi.org/10.17811/ rifie.47.2.2018.149-158

Rodríguez-Brown, F. V. (2009). The home-school connection: Lessons learned in a culturally and linguistically diverse community. New York: Routledge.

Rong, X. L., \& Preissle, J. (2009). Educating Immigrant Students in the 21st Century: What Educators Need to Know. Thousand Oaks, Calif: Corwin Press.

Roses in Concrete Community School (2016). Our Mission. Retrieved January 31, 2017, from http://rosesinconcrete.org/ our-mission/

Seattle Public Schools (2017). School-Family Partnerships. Retrieved January 5, 2017, from http://www.seattleschools. org/families_communities/schoolfamilypartnerships/

Sheldon, S. B. (2003). Linking school-family-community partnerships in urban elementary schools to student achievement on state tests. The Urban Review, 35(2), 149-165. doi: https://doi.org/10.1023/A:1023713829693

Shockley, B., Michalove, B., \& Allen, J. (1995). Engaging families: Connecting home and school literacy communities. Portsmouth, NH: Heinemann. 
Smit, F., \& Driessen, G. (2005). Ethnic minority parents' and teachers' orientation on collaboration between home and school: Strategies and contexts. Aula Abierta, 86, 169-184.

Simon, B. S., \& Epstein, J. (2001). School, family, and community partnerships: Linking theory to practices. In D. HiattMichaels (Ed.), Promising practices for family involvement in schools (pp. 1-24). Greenwich, CN: Information Age.

Tagawa, B. (2014). Oakland school will train teachers to nurture "roses in concrete." Retrieved January 31, 2017, from https:// news.sfsu.edu/oakland-school-will-train-teachers-nurtureroses-concrete

Thao, Y. J. (2003). Empowering Mong students: Home and school factors. The Urban Review, 35(1), 25-42.doi https://doi. org/10.1023/A:1022675022518

U.S. Census Bureau (2012, May 17). Most Children Younger Than Age 1 are Minorities, Census Bureau Reports. Retrieved May 20, 2018, from https://www.census.gov/newsroom/releases/ archives/population/cb12-90.html
U.S. Census Bureau (n.d.). Newsroom. Retrieved May 20, 2018, from https://www.census.gov/newsroom.html

U.S. Department of Education (2007, September 14). Title I-Improving the academic achievement of the disadvantaged: Improving Basic Programs Operated by Local Educational Agencies (I-A) [Reference Materials; Policy Guidance]. Retrieved May 21, 2018, from https://www2.ed.gov/admins/ lead/account/nclbreference/page_pg4.html\#titlei

U.S. Department of Education (n.d.). No Child Left Behind ED.gov. Retrieved May 21, 2018, from https://www2.ed.gov/ nclb/landing.jhtml?src=ln

Walberg, H. J., \& Paik, S. J. (1997). Home environments for learning. In H.J., Walberg \& G. D., Haertel (Eds.), Psychology and educational practice (pp. 356-368). Berkeley, CA, McCutchan Publishing.

Wilson, E. (2015, August 24). Why There Are High Rates of PTSD In This Teacher's Classroom. AlterNet. Retrieved from http:// www.alternet.org/education/why-there-are-high-rates-ptsdteachers-classroom 
